\title{
A RANDOM WALK THROUGH TIME
}

\author{
Minze Stuiver \\ Professor Emeritus, University of Washington, Department of Geological Sciences \& Quaternary Research Center, Seattle, \\ Washington 98195, USA. Email: minze@u.washington.edu.
}

A celebration is in order: the journal Radiocarbon is now a mature 50 years without drastic changes in its identity. There have been, of course, additions in terms of specific isotopes (it is now an international journal of cosmogenic isotope research), but the ${ }^{14} \mathrm{C}$ content is still very extensive. The triannual offshoots, conference proceedings (started in 1980), and calibration issues (the first in 1986) testify to the strength of the ${ }^{14} \mathrm{C}$ component.

The following notes discuss a few historical aspects of my participation in the journal and its field of science. Some personal notes are also included. Advanced age $\left(1 \%{ }^{14} \mathrm{C}\right.$ decay would not be far off) is usually a good excuse for these wanderings.

The calibration of a ${ }^{14} \mathrm{C}$ age transfers a number on the ${ }^{14} \mathrm{C}$ timescale to one or more years on the calendar year scale. This is the scale we are most familiar with, and time is our permanent companion. For us, it moves in one direction only; tomorrow cannot precede today. Past events are stored as memory during life, but the brain-recorded memories are not permanent. Aging produces memory loss; events become hazy and distortions occur. A rigorous memory calibration is not possible, and the reader has to assume that the reflections in this note are part of reality. I am convinced they are!

Thanks to the internet, the scientific aspects of my career can easily be found. What is missing is the person - why oh why did I ever end up in the carbon and oxygen isotope field? That field, after all, is only a small item in this universe.

Random events played a role, already from the very beginning, with my birth and the start of the global depression only 2 days apart. A decade later, the Second World War interfered with my formative years in the city of Almelo, the Netherlands (the city where Abdul Qadeer Khan spent a year and copied isotope enrichment secrets at URENCO for the Pakistani nuclear bomb program in 1976).

My father was a customs official at the German-Dutch border, while mother took care of the housework for all 5 of us ( 2 younger sisters included). The Almelo home was very basic; these were the depression years. One cold water faucet for the family and 1 stove for cooking, both in the kitchen; 1 stove for heating in the living room; and 1 toilet with ice on the enclosing walls during winter time. A great event was our weekly bath, with warm water in a large metal pail in front of the living room stove.

The war played havoc with $3 \mathrm{yr}(1942-45)$ of high school education. The school was occupied by German soldiers and classes were held, if at all, in the public library, bathhouse, textile factory, etc. The sessions in the textile factory were especially annoying, with German propaganda and military music on the loud speakers preempting our teacher. Interruptions by air raids were common, and I saw many table undersides. Lots of cancelled classes produced much time for tending the vegetable garden, an important tool for survival. I also collected milk 3 times a week from a farmer ( 2 hours roundtrip on a bike with tires made of pieces of wood - no rubber plantations in Holland!). On one of those trips, I contemplated the wreckage of one of the world's first Messerschmitt Jet fighters on a farmer's land. Food was of such importance that my father traded my coat for butter and eggs on one of our fishing trips. The late autumn return trip (a couple of hours on the bike) was very windy and cold.

C 2009 by the Arizona Board of Regents on behalf of the University of Arizona Celebrating 50 Years of Radiocarbon

RADIOCARBON, Vol 51, Nr 1, 2009, p 291-300 
My war tales are much appreciated by my daughters. These tales center around $2 \mathrm{yr}$ without electricity (a single candle for light in the evenings), V-1 and V-2 missiles launched near Almelo, innumerable American planes overhead on the way to Germany (counting 1000 Flying Fortresses, each with nearly 5 tons of bombs, in a single afternoon), "razzia's" to round up people for forced labor in Germany, hiding an uncle in my freshly dug "bomb shelter," escaping a Gestapo raid when listening to the BBC (capital punishment on that act), being shot at by a formation of 4 Spitfires, and searching for lapwing eggs in the meadows between the German and Canadian lines. (Dad had an agreement with the dug-in Canadian soldiers that they first would fire over our heads so that we could hit a ditch, which we did a couple of times.) As teenagers we were rather callous to danger and resorted to making our own gunpowder (each of the three of us would buy a single component), filling spent cartridges left by Canadian troops, and explode these as firecrackers. Terrorist activities indeed!

Are all these experiences at all relevant to present-day society? Yes, very much so. For instance, I learned from $5 \mathrm{yr}$ of German propaganda that only facts are relevant in politics. (I did not believe for one minute the weapons of mass destruction tales that started the Iraq war-real facts were not there.) And don't let me start on torture.

Starting in 1947, life at the University of Groningen with about 2000 students was more peaceful. This small university contributed much to society. Here Willem J Kolff received his $\mathrm{PhD}$ degree in 1946 on the artificial organ and hemodialysis treatment. Millions of kidney patients improved their health based on this work. Just to stay within my own environment, I attended Prof Dirk Coster's physics classes. He was codiscoverer of the element hafnium, and personally brought Lise Meitner (codiscoverer of uranium fission) over the Dutch-German border in 1938 during her escape from Nazi Germany. There was Prof Frederic Zernike, the only professor who wanted to see additional work before I passed his examination in statistical physics. He was the 1953 Nobel Prize winner for inventing the phase contrast microscope. It is now impossible to visualize any biotech or medical research facility around the world without this tool. Maarten Schmidt, (the 2008 recipient of the Kavli Science Prize), an astronomer at Mt Palomar Observatory in the US, was a fellow student in astronomy class. Prof P H Kuenen, with his office next to the physics lab, was the recipient of the Penrose Medal of the American Geological Society (another Penrose Medal is in my desk, awarded in 2005). And then, of course, there was Prof Hessel de Vries, famous for his work in biophysics (there were many visits of science attachés) and ${ }^{14} \mathrm{C}$ dating.

Study subjects during the first $3 \mathrm{yr}$ in Groningen were physics, mathematics, and astronomy. In 1950, I focused on nuclear physics, installing among others a small betatron for the Physics Department. After graduation ("doctoraal") in 1950, I joined the biophysics group of Hessel de Vries and wrote a thesis on "The Biophysics of the Sense of Smell." A very interesting aspect of the sense organs is their sensitivity. Sense cells of the eye respond to 1 quantum of light, and the ear has a sensitivity that comes close to Brownian motion. The thesis demonstrated, among others, that an olfactory receptor responds to a very small number of odorous molecules, most likely only one for some compounds. Strongly diluted mercaptans were used, and I was banned to the far reaches of the physics department. Nevertheless, there were occasionally vociferous objections by many persons of "non-biophysical interest."

De Vries (Figure 1), with his diversified interests in various fields, did not really allow a $100 \%$ dedication to thesis work. I was drafted as a substitute during a professorial soccer game, and construction of quartz counters with low backgrounds was important. The other extreme was the freeze-drying of an archaeological wood specimen (pole in out terminology) from a peat bog. Part of the pole was frozen to $-40{ }^{\circ} \mathrm{C}$ and pumped dry in a vacuum jar. The weight of the pole, as well as the amount of water removed from the pole, was determined as a function of time. It took 2 weeks to remove the 
water with pole temperatures varying from -10 to $-25^{\circ} \mathrm{C}$. The sample lost $87 \%$ of its weight. I also lost a lot of sleep feeding dry ice to the system every $2 \mathrm{hr}$ for the first couple of days because automated temperature control was nonexistent in 1954.

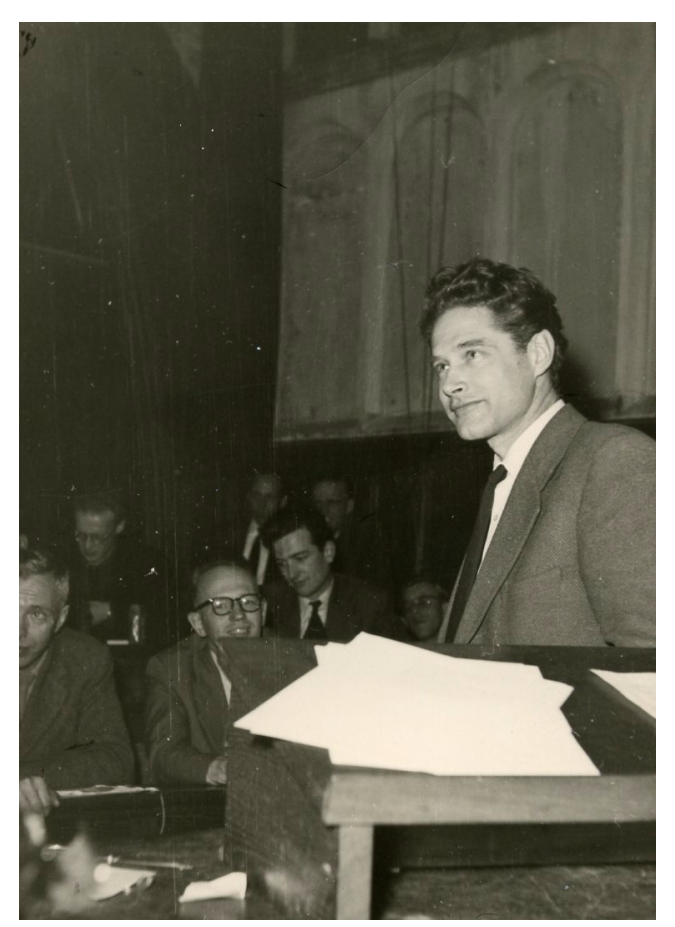

Figure 1 Hessel de Vries lecturing in Groningen in the mid-1950s. In the front row: Professors Groenewold and De Waard.

A major attraction of the Physics Department ("Natuurkundig Laboratorium") was its administration. Anneke, a talented and charming girl, was in charge. Our marriage (with 2 daughters, Ingrid and Yolande) is now in its 52nd year. The University's policy was to dismiss female administrative members upon marriage. Times were changing, however, and with the help of the Physics Lab director this policy was overturned.

AD 1958 was the first year of submergence in ${ }^{14} \mathrm{C}$. Not entirely coincidental, after all Hessel de Vries was the mentor for the biophysics $\mathrm{PhD}$ thesis. The 1950s saw the birth of ${ }^{14} \mathrm{C}$ dating by W F Libby and coworkers, using a solid carbon sample in a screen-wall counter. The next step was to use carbon dioxide as a counting gas and measure the ${ }^{14} \mathrm{C}$ activity of the gas directly in a proportional counter. De Vries was the first one to produce sufficiently purified $\mathrm{CO}_{2}$ gas, together with $\mathrm{G} \mathrm{W}$ Barendsen (de Vries and Barendsen 1952), whose 1955 thesis (in the Dutch language) describes the method in great detail (Barendsen 1955). There was much improvisation; the only space available for the initial shield plus counter was a restroom. After toilet removal, the experiments were quite successful. The next step was to construct a ${ }^{14} \mathrm{C}$ laboratory (Figure 2).

De Vries (1958) found variations in concentration of ${ }^{14} \mathrm{C}$ with time on Earth. This paper led to great torment because ${ }^{14} \mathrm{C}$ dates are based on the assumption of constant initial activity. Accounting for these variations through ${ }^{14} \mathrm{C}$ age calibration became very important in the following years. My own work in 1958-59 involved the "modeling" of these atmospheric ${ }^{14} \mathrm{C}$ variations. Present-day modeling was nearly impossible during the 1950s, given the absence of computers. Once in a while, however, one could get results. I was interested in the ${ }^{14} \mathrm{C}$ production rate changes tied to the sunspot 


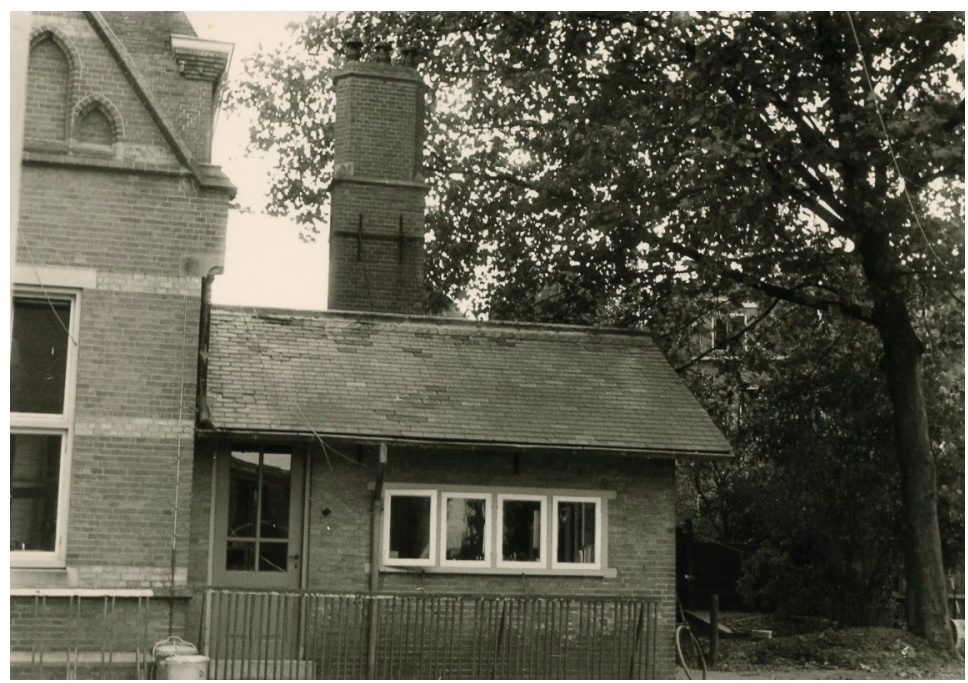

Figure 2 De Vries used this small annex to the Physics workshop for his pioneering ${ }^{14} \mathrm{C}$ work.

cycle. The approximate size, and exchange rates, between the global carbon reservoirs were known from Harmon Craig's work (Craig 1957) and could be converted into an electric analogue where the reservoirs were presented by condensers and the exchange rates (and ${ }^{14} \mathrm{C}$ decay) by resistors. A metal sheet, with the sunspot record of the last $400 \mathrm{yr}$ carved on its edge, was mounted on the axis of the motor. While rotating, the edge of the sheet intercepted part of a light beam striking along the edge of the sheet. The light intensity variations were converted by a photomultiplier into electrical current variations, and fed into the model. The current variations provided an "electrical" sunspot curve, and the modified responses of the electric analogue were observed with an oscilloscope. All in all, a far cry from present-day computer modeling, but, fortunately, the results (Stuiver 1961) were equally valid.

In September 1959, we hosted an international ${ }^{14} \mathrm{C}$ conference in Groningen. There were 45 participants. Wally Broecker, with a brand-new $\mathrm{PhD}$ degree, was one of the rising stars. The ${ }^{14} \mathrm{C}$ conference was a great success even though several participants were surprised by the clientele in the hotel recommended by the organizers. The hotel was near Groningen's red light district.

In late September, Anneke and I traveled to New Haven, Connecticut. Prof Ed Deevey of the Geochronometric Laboratory at Yale University needed help in running the lab and offered a 1-yr postdoctoral fellowship. The University of Groningen granted a 1-yr leave. We were eager to return to Groningen after that year because a brand-new ${ }^{14} \mathrm{C}$ laboratory was under construction. But after 3 New Haven months, the random arrow struck with the sudden death of de Vries a few days before Christmas 1959. A speedy return, to head the Groningen ${ }^{14} \mathrm{C}$ unit, was requested, but there also was a decision by the physics lab director that the newly constructed space would not be available for ${ }^{14} \mathrm{C}$ research. This issue was ultimately decided by the Secretary of Education and Research in The Hague in favor of the ${ }^{14} \mathrm{C}$ unit. There were some battle scars from this struggle, and Anneke and I agreed that continuing at Yale was better for our future.

Yale, of course, is the birthplace of the journal Radiocarbon. Editors Richard Foster Flint and Edward S Deevey, with support of the National Science Foundation, generated the first issue (called Radiocarbon Supplement) under the aegis of the American Journal of Science in 1959. During the 
early 1950 s, each ${ }^{14} \mathrm{C}$ date gave important new information, and many publications saw the light. Later on, with several laboratories on line, date lists became more standard and regular journals (e.g. Science) were not interested in publishing the listings. As noted in the Volume 1 preface, the editors stated, "We hope that the SUPPLEMENT will serve henceforth as the medium for primary publication of all radiocarbon measurements, or at least of radiocarbon date lists." The emphasis on date lists was especially strong during the first $20 \mathrm{yr}$ of its existence. The number of editors grew, with 4 editors by 1972 (including yours truly) plus a managing editor (Renee Kra started in 1968). The group of editors was separated in 1977 with Minze Stuiver as senior editor, Renee Kra as managing editor, and 3 other scientists as editors. A statement in the 1977 number 1 issue notes that "articles containing scientific knowledge derived from ${ }^{14} \mathrm{C}$ data should broaden the scope of the journal and increase its readership. Starting immediately, the editors of Radiocarbon will consider such articles for publication." The new policy resulted in publishing the proceedings of the Tenth International Radiocarbon Conference 1979 (Bern/Heidelberg) as part of the journal. The Bern/Heidelberg issue became the prototype of the proceedings of the international ${ }^{14} \mathrm{C}$ conferences subsequently held in Seattle, Trondheim, Dubrovnik, Tucson, Glasgow, Groningen, Jerusalem, Wellington, and Oxford. The number of attendees grew from 45 in Groningen (1959) to 289 in Oxford (2006).

Age calibration assigns a calendar date, or multiple dates, to a single ${ }^{14} \mathrm{C}$ age. Tree-ring chronologies became the backbone of the calibration effort in the 1960s. An early paper in Radiocarbon (Stuiver and Suess 1966) gave a 1000-yr-long calibration curve. Many extensions by various researchers followed. Measurement precision and accuracy also became very important. In 1982, the disjointed data sets were integrated by a dozen or so researchers meeting in Tucson into an internationally acceptable database. The 1986 calibration issue of the journal Radiocarbon followed and included the initial version of the age calibration program CALIB (Stuiver and Reimer 1986). The integrated calibration curve in the 1986 issue was ratified by the participants of the International Radiocarbon Conference. Other internationally approved calibration curves followed in the calibration issues of 1993 (with the IBM-compatible computer program CALIB 3.0), 1998, and 2004. Dendrochronologically dated wood covers at least 12,000 yr by now but does not, as yet, extend over the entire ${ }^{14} \mathrm{C}$ dating range. The 1998 issue (IntCa198) already included records of U/Th-dated corals and foraminifera from varved marine sediments (Stuiver et al. 1998). The current IntCal working group recommends an international calibration curve back to $26 \mathrm{kyr}$ BP. A discussion of a possible extension to $50 \mathrm{kyr}$ is given by P J Reimer in her introduction to the IntCal04 calibration issue (Reimer 2004).

In 1987, there were some heartfelt objections to chasing too many projects and after surgery I vacated the senior Editor position. The American Journal of Science also relinquished its oversight and the University of Arizona became its new steward. Ever since, the journal has prospered in the Arizona desert with the guidance of senior editors A Long and A J T Jull.

The Yale Geochronometric Lab (changed to Radiocarbon Lab after the move to Kline Geology) had an ideal administrative arrangement during my decadal sojourn at Yale. It was independent of the regular academic units, and did not suffer from departmental interference. The provost (Kingman Brewster initially) was in charge. During the move to Kline Geology, a newly constructed building, there was a lot of competition for the funds available for instrumentation, lab benches, and other finishing touches. The provost gave us top priority. The departmental chairman visited the lab upon completion, took a few steps inside, and left very quickly muttering, "This was never my intention."

Many projects were initiated; it was a golden age for ${ }^{14} \mathrm{C}$ work. Counters with low backgrounds had to be constructed and anti-coincidence arrangements had to be improved upon. Extending the dating range and tree-ring-sunspot work, as noted previously, became very important. Archaeological undertakings included ${ }^{14} \mathrm{C}$ dating of iron ( $\mathrm{N} \mathrm{J}$ van der Merwe), the dating of mortar (C S Smith) and 
Talyotic lime burials (W H Waldren). Glacial ice was dated (G H Denton) and submergence rates of the Connecticut (A Bloom), New Jersey (J J Daddario), and Florida (D W Scholl) coasts determined. Long-term atmospheric ${ }^{14} \mathrm{C}$ change was calculated for Lake of the Clouds varves (Stuiver 1970b) and post-glacial uplift rates computed for Mesters Vig, Greenland (A L Washburn). Peat bogs were cored to determine the end of the marine invasion in coastal Maine and a great benefit was 3 summers of tent camping in state parks with the Hal Borns family (Stuiver and Borns 1975). But my heart was in the study of lake waters and sediments. Ed Deevey was the cause-within 2 days after arrival at Yale he took me water sampling at Linsley Pond (the house lake of Hutchinson and Deevey). Hardwater effects were important for ${ }^{14} \mathrm{C}$ dating, but I was mainly interested in the sulfur cycle and oxygen isotopes. Sulfur-35 was used as a tracer (Stuiver 1967). On a beautiful day in October 1964, we collected hydrogen sulfide gas from the deep stratified waters (hypolimnion) of the lake. We used a floating platform with a nitrogen tank feeding nitrogen gas through a tygon tube to 14-m depth, just underneath an inverted funnel with apex connected to another tygon tube that made the nitrogen gas plus any sulfur hydroxide bubble back to the surface. On the platform, we precipitated the sulfur in a cadmium acetate solution as cadmium sulfide. (The radioactivity of the cadmium sulfide was determined in a planchet counter.) It took nearly $6 \mathrm{hr}$ to get a single sample. We worked near the end of the seasonal stratification, and the deep and upper lake waters mixed a couple of days later. Back in the lab, we noticed in the cadmium acetate solution not only the desired cadmium sulfide but also a black droplet. One of the technicians with a degree in analytical chemistry was assigned the task of identifying the droplet. She reported a rather unbelievable conclusion: it was mercury. The experiment could not be repeated until a year later and we never went back. A big mistake (never focus solely on isotopes!) because several years later a couple of Swedish scientists made headlines with the discovery of methylmercury in the freshwater environment. It also explained my miserable stomach after eating a Linsley Pond perch (top of the food cycle) during that year.

Oxygen isotopes were not neglected, despite our lovefest for ${ }^{14} \mathrm{C}$ and sulfur. ${ }^{18} \mathrm{O} /{ }^{16} \mathrm{O}$ ratios of marl and shells from several lakes were used as climatic indicators (Stuiver 1968, 1970a). But it was time to move to another place; the Yale position was in research only. The University of Washington with its ex-Yale members A L Washburn, S C Porter, and M Tsukada beckoned. I became the latest addition to the "Yale Mafia" at the UW Quaternary Research Center.

Upon my arrival in 1969, the Quaternary Isotope Laboratory (QIL) was an exercise on paper only. Construction of the building was completed in September 1972, and the first measurements made in March 1973. The GEOSECS (Geochemical Ocean Section Study) with its worldwide sampling program was launched. All ${ }^{14} \mathrm{C}$ samples collected for this decadal program were measured at our lab and the Tritium Laboratory of Gote Ostlund (University of Miami). Shipboard testing of sample collection lines was started in 1971. My participation on a 3-week Antipode Expedition between Samoa and Tonga was a mixed blessing. The ${ }^{14} \mathrm{C}$ collection system worked well, but the Pacific swell created seasickness for the entire 3 weeks. I was the only one on board with this affliction, lost 10 pounds, and was the butt of a few jokes (Figure 3).

Another somewhat random event was the creation of the much-used paper on the reporting of ${ }^{14} \mathrm{C}$ data (Stuiver and Polach 1977). Henry Polach, after attending the 1976 International Radiocarbon Conference in California, arrived in Seattle with a major complaint. He had been unable to get a coherent answer on data reporting at the meeting. I had just spent a lot of time researching that topic - the first GEOSECS data had to be reported. Henry's questions were answered during a sunny hour at our picnic table, and the outline of the paper was produced (Figure 4). Henry wrote a very kind letter to the family afterwards and concluded, "Minze, when I think of you I think of work. I know you would want me to." 


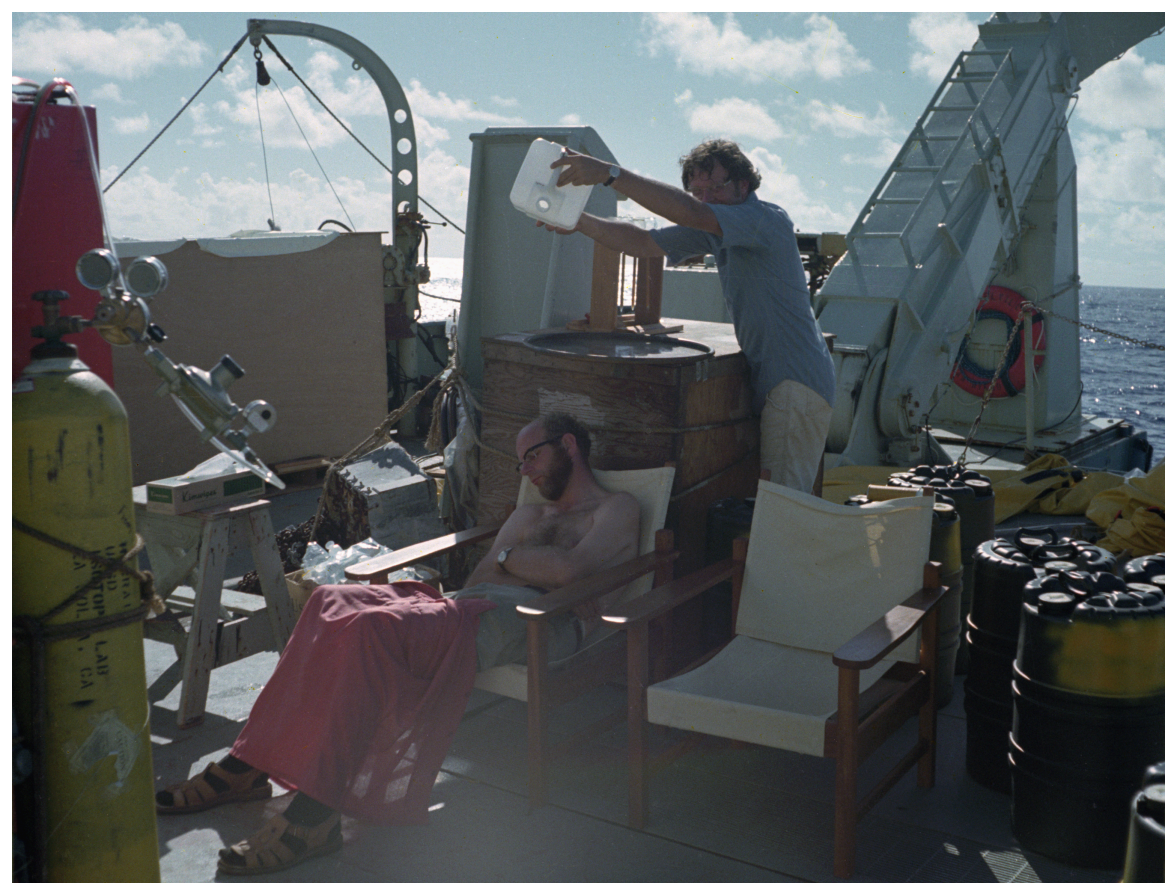

Figure 3 Wally Broecker pouring water over a dozing (seasick?) Minze Stuiver. A Harmon Craig photograph archived at the Scripps Institute of Oceanography (SIO). Printed with permission from SIO.

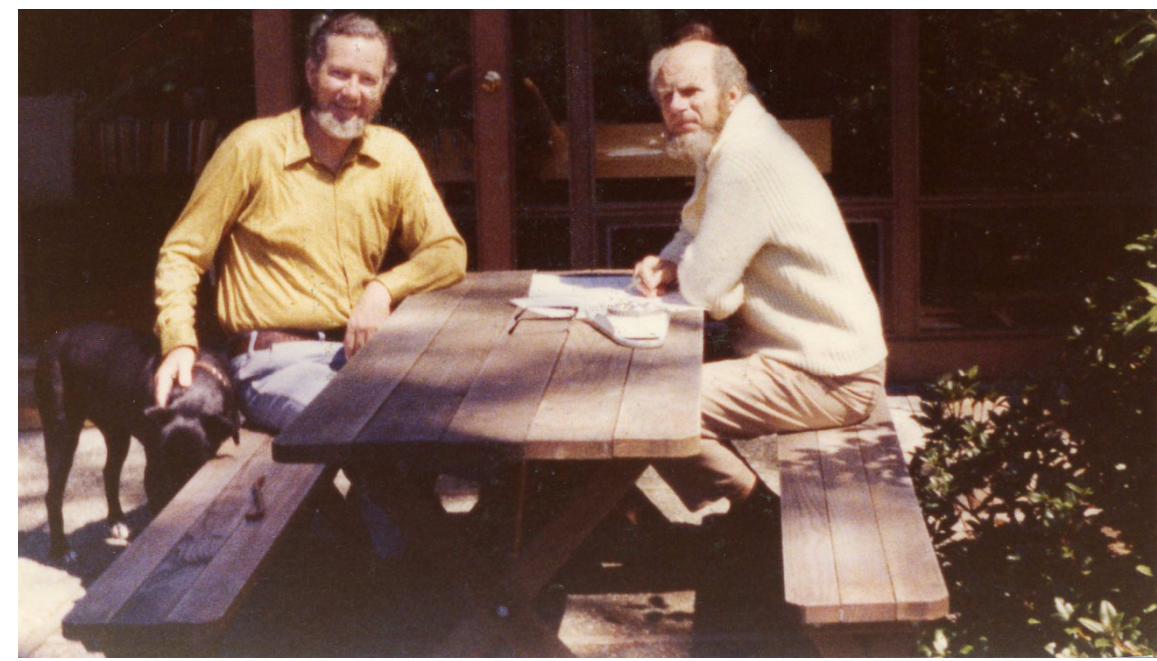

Figure 4 Henry Polach, Minze Stuiver, and dog Suzy generating the data reporting paper in Bellevue, Washington.

${ }^{14} \mathrm{C}$ isotope enrichment was applied, bringing the $0.1 \%$ detection limit (equivalent with a $75,000-\mathrm{yr}$ sample age) in sight (Stuiver et al. 1978). This method needs very large samples, a lot of equipment, and much patience (about 6 samples were measured per year). Tree-ring research was extended beyond ${ }^{14} \mathrm{C}$ age calibration with the use of ${ }^{18} \mathrm{O} /{ }^{16} \mathrm{O}$ and ${ }^{13} \mathrm{C} /{ }^{12} \mathrm{C}$ ratios of cellulose for climate trends (Burk and Stuiver 1981) and global carbon reservoir changes (Stuiver 1978). For instance, the ${ }^{13} \mathrm{C} /$ 
${ }^{12} \mathrm{C}$ isotope trend was compatible with a reduced total terrestrial biomass of $7 \%$ between $\mathrm{AD} 1850$ and 1950. By now, these topics are quite popular as part of global climate change, but interest was rather minimal during my first carbon cycle change lecture in 1971. Atmospheric ${ }^{14} \mathrm{C}$ changes resulting from fossil fuel $\mathrm{CO}_{2}$ release and cosmic-ray flux variability were evaluated (Stuiver and Quay 1981) and the abyssal water ${ }^{14} \mathrm{C}$ distribution and the age of the world oceans determined (Stuiver et al. 1983). Climatic information was derived from the Greenland GISP and Antarctic Taylor Dome ice cores. Oxygen isotope ratios were measured for corals and yielded the first ${ }^{18} \mathrm{O} /{ }^{16} \mathrm{O}$ record of El Niño events. Solar variability and ${ }^{14} \mathrm{C}$ age calibration, of course, were not neglected.

Scientific meetings were an important tool for the dissemination of recently acquired knowledge. Not all talks are exciting, but there was usually enough brain cell stimulation to compensate for the time lost in the lab. Skipping a day at a meeting also can have its benefits: I spent a day alone in the Hermitage during the non-touristic Soviet Union era. Other activities are also possible (Figure 5).

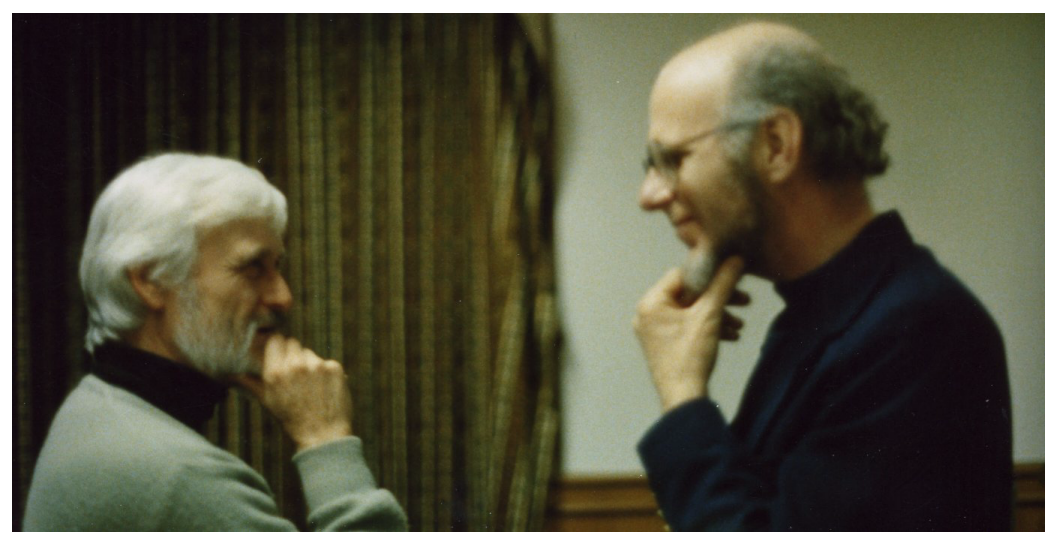

Figure 5 Paul Damon and Minze Stuiver contemplating beard growth, Tucson 1979

Hotel stays can be occasionally nerve-racking. On a very warm day, my friend Wally S Broecker returned to his hotel room on the 4th floor yearning for some fresh air. He forced the window open, and the air conditioner fell on the street. That, of course, called for a very early departure the following morning. My own stay at the Rabat Hilton also had an odd component. To start with the beginning, I was invited in 1984 by the King to come to Morocco for advice on climate research. The invitation was accompanied by a Persian carpet, and travel was first class. There was a car with a Royal Palace driver on 24-hr standby, and I was lodged at the Hilton on the floor usually reserved for the King's visitors. I did not see Yasser Arafat (he was on the same floor), but on the second day my room was encircled by an Arab Sheik with 3 young wives. There was much nightly activity in their rooms. Access to my room also had some obstacles; at each end of the hall there were rough-looking bodyguards of the Sheik sitting with drawn guns. When one of the ladies showed some slight interest in my well-being, I quickly asked to be relocated to another floor.

The multitude of isotope projects called for the participation of many. It was a privilege to work, among others, with coworkers Paul Quay, Piet Grootes, Tom Braziunas, and Bob Burk. A great success story was a young, dapper girl hired as a computer technician in 1977. She developed the computer aspects of the CALIB program, produced a PhD thesis on the carbon cycle in lakes, and more recently joined the Belfast ${ }^{14} \mathrm{C}$ and climate program. Her name, of course, is Paula Jo Reimer, one of the editors of this calibration section. She is part of a professorial quartet produced by the lab (P Quay, University of Washington; P M Grootes, University of Kiel; P J Reimer, Queen's Univer- 
sity Belfast; and E J Steig, University of Washington). Many researchers contributed to the highprecision ${ }^{14} \mathrm{C}$ work with actual data as well as tree-ring calibrated wood samples. They became great friends - Gordon Pearson of Queen's University Belfast, Bernd Kromer of the University of Heidelberg, and Bernd Becker of the University of Stuttgart (Figures 6 and 7).

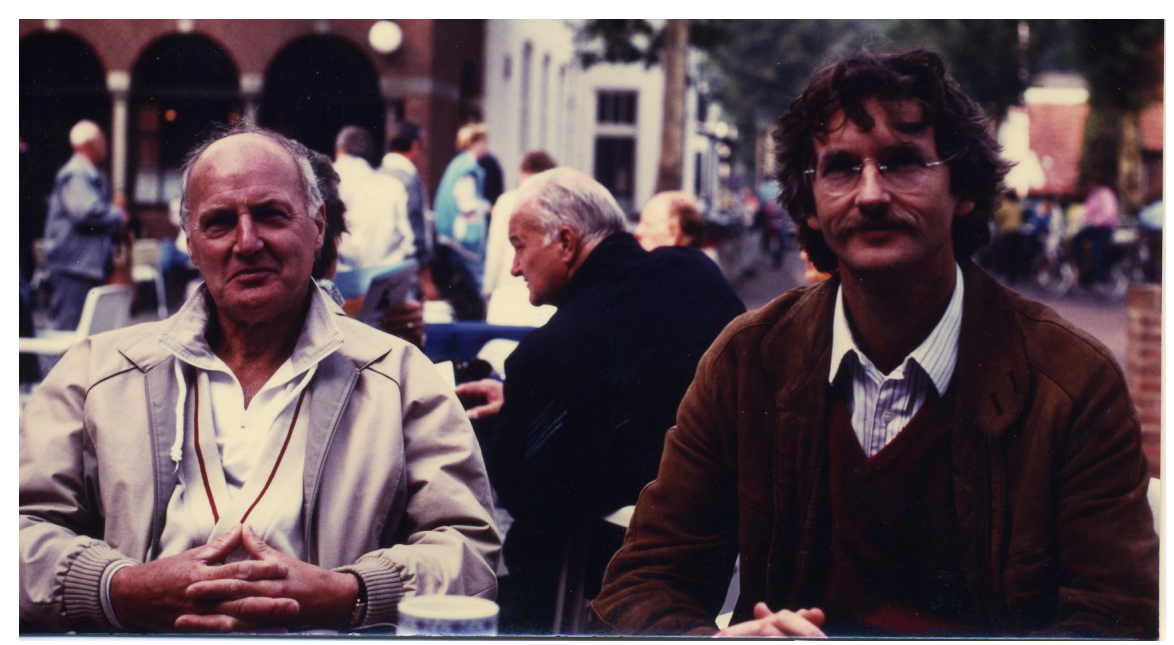

Figure 6 Gordon Pearson and Bernd Kromer enjoying a beer on one of the Friesian Islands, the Netherlands.

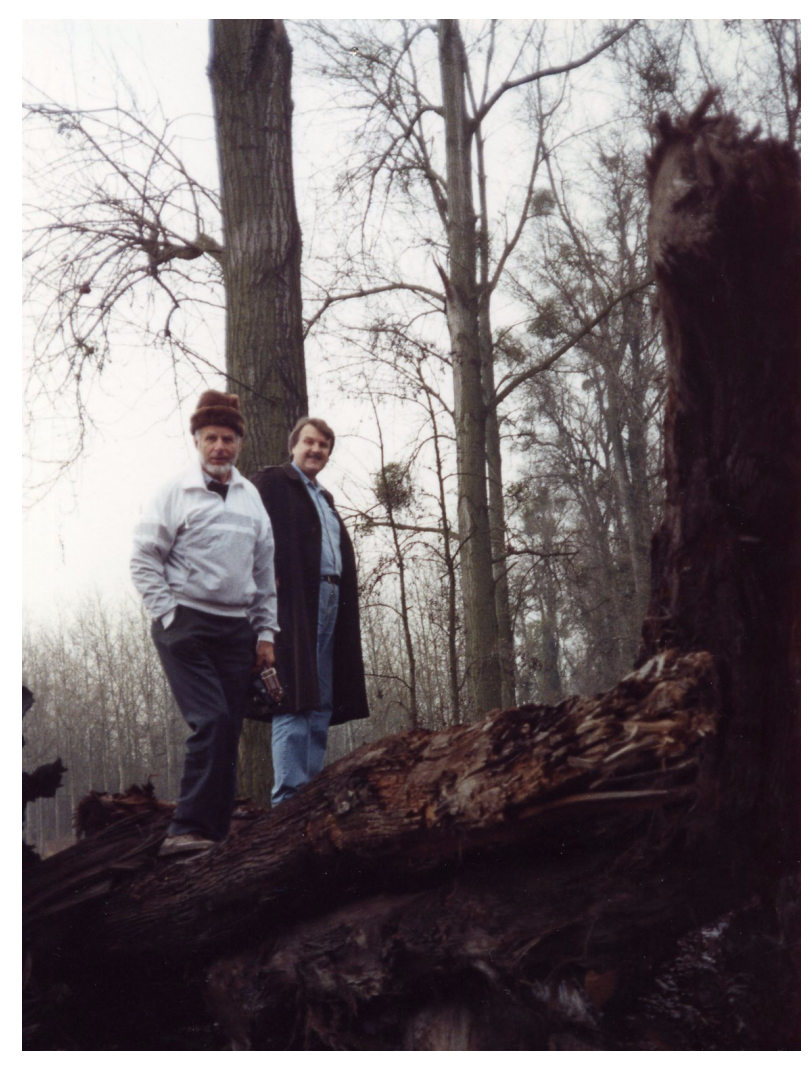

Figure 7 Minze Stuiver and Bernd Becker on a fossil oak log in the Rhine Valley, Germany. 
Retirement was called for in late 1998. After the usual play of academic self-interests and back stabbing, a successor was selected without an interest in running the Quaternary Isotope Lab. The lab was closed and dismantled to the last stopcock. Several years later, the stable isotope component was resurrected by Eric Steig.

There are certain advantages to retirement, but it is usually accompanied by aging. For instance, these notes were written without a change in heartbeat, as the pacemaker is set at $60 \pm 0.1 \mathrm{~Hz}$. As a whole, I tend to agree with Reidar Nydal's observation in Radiocarbon, starting with "At an early stage in my childhood I regarded retirement as a kind of illness." Old age has another aspect; there is too much past to describe. But the memories of so many friends and colleagues keep the fire burning.

The journal Radiocarbon need not worry about its 50 years; life expectancies of a great journal are several times that of a human being. And calibration research is crucial. Time should be measured and calibrated. But beware, tempus fugit.

\section{REFERENCES}

Barendsen GW. 1955. Ouderdomsbepaling met Radioactive Koolstof [PhD dissertation]. Groningen: University of Groningen. In Dutch.

Burk RL, Stuiver M. 1981. Oxygen isotope ratios in trees reflect mean annual temperature and humidity. Science 211(4489):1417-9.

Craig H. 1957. The natural distribution of radiocarbon and the exchange time of carbon dioxide between atmosphere and sea. Tellus 9:1-17.

de Vries H. 1958. Variation in concentration of radiocarbon with time and location on earth. Proceedings of The Koninklijke Nederlandse Akademie Van Wetenschappen Series B 61:94-102.

de Vries H, Barendsen GW. 1952. A new technique for the measurement of age by radiocarbon. Physica 18(8-9):652.

Reimer PJ. 2004. From the Guest Editor. Radiocarbon 46(3):v-vi.

Stuiver M. 1961. Variations in radiocarbon concentration and sunspot activity. Journal of Geophysical Research 66(1):273-6.

Stuiver M. 1967. Origin and extent of atmospheric ${ }^{14} \mathrm{C}$ variations during the past 10,000 years. In: Radioactive Dating and Methods of Low-Level Counting. STI/ PUB/152. Vienna: IAEA. p 27-40.

Stuiver M. 1968. Oxygen-18 content of atmospheric precipitation during the last 11,000 years in the Great Lakes region. Science 162(3857):994-7.

Stuiver M. 1970a. Oxygen and carbon isotope ratios of fresh-water carbonates as climatic indicators. Journal of Geophysical Research 75(27):5247-57.
Stuiver M. 1970b. Tree ring, varve and carbon-14 chronologies. Nature 228(5270):454-5.

Stuiver M. 1978. Atmospheric carbon dioxide and carbon reservoir changes. Science 199(4326):253-8.

Stuiver M, Borns Jr HW. 1975. Late Quaternary marine invasion in Maine: its chronology and associated crustal movement. Geological Society of America Bulletin 86(1):99-104.

Stuiver M, Polach HA. 1977. Discussion: reporting of ${ }^{14} \mathrm{C}$ data. Radiocarbon 19(3):355-63.

Stuiver M, Quay PD. 1981. Atmospheric ${ }^{14} \mathrm{C}$ changes resulting from fossil fuel $\mathrm{CO}_{2}$ release and cosmic ray flux variability. Earth and Planetary Science Letters 53(3):349-62.

Stuiver M, Reimer PJ. 1986. A computer program for radiocarbon age calibration. Radiocarbon 28(2B): $1022-30$.

Stuiver M, Suess HE. 1966. On the relationship between radiocarbon dates and true sample ages. Radiocarbon 8:534-40.

Stuiver M, Heusser CJ, Yang IC. 1978. North American glacial history extended to 75,000 years ago. Science 200(4337):16-21.

Stuiver M, Quay PD, Ostlund HG. 1983. Abyssal water carbon-14 distribution and the age of the world oceans. Science 219(4586):849-51.

Stuiver M, Reimer PJ, Bard E, Beck JW, Burr GS, Hughen KA, Kromer B, McCormac G, van der Plicht J, Spurk M. 1998. INTCAL98 radiocarbon age calibration, 24,000-0 cal BP. Radiocarbon 40(3):104183. 